\title{
FIRST RECORDS OF PSILOCHILUS MODESTUS AND ELLEANTHUS HIRTZII (ORCHIDACEAE) FROM COLOMBIA
}

\author{
Dariusz L. SzlachetKo \& Marta Kolanowska ${ }^{1}$
}

\begin{abstract}
Two Orchidaceae species, Psilochilus modestus Barb. Rodr. and Elleanthus hirtzii Dodson, are reported for the first time from Colombia. Previously the latter orchid was reported only from Ecuador. Psilochilus modestus was known from Bolivia, Brazil and Venezuela. The morphological descriptions of the specimens from Colombia are complemented with brief notes on their diagnostic characters.
\end{abstract}

Key words: biodiversity, distribution, Elleanthus, Neotropics, Psilochilus

Dariusz L. Szlachetko \& Marta Kolanowska, Department of Plant Taxonomy and Nature Conservation, University of Gdańsk, Wita Stwosza 59, 80-308 Gdańsk, Poland; e-mail: martakolanowska@wp.pl

\section{INTRODUCTION}

Colombia is one of the most biodiverse countries in the world. Representatives of 294 vascular plant families and 2302 genera are found there. The most diverse of them are the Orchidaceae, with over 3500 species (Jørgensen et al. 2011). Orchids are found in Colombia in various ecosystems, including desert regions, mangrove forests, tropical savannas, and paramo (Orejuela 2005), but most of them are found in various types of Andean forest (Meisel \& Woodward 2005).

The latest detailed list of Colombian orchids compiled by Ortiz Valdivieso and Uribe Vélez (2007) contains information on almost 3000 species and subspecies occurring there. That makes Columbia one of the most important centers of Orchidaceae diversity, as more than $10-12 \%$ of all known species of this family occur in that country (Orejuela 2005). In research published by Jørgensen et al. (2011) the number of Colombian orchids increased to 3588 , but without an exact list of those species given.

Since the publication of Galería de orquideas de Colombia (Ortiz Valdivieso \& Uribe Vélez 2007) new records of Orchidaceae occurring in

\footnotetext{
1 Corresponding author
}

the country are continuously appearing (e.g., Kolanowska 2012; Kolanowska \& Szlachetko 2013; Kolanowska et al. 2012, 2013; Pérez Escobar et al. 2011, 2013). Here we present recent findings of orchids not registered in Colombia so far. The novelties belong to the genera Psilochilus and Elleanthus. The morphological descriptions of the specimens found in Colombia are complemented with brief notes on their taxonomic affinities.

The genus Psilochilus was described by Barbosa Rodrigues in 1882. Its representatives produce fleshy, villous roots along the creeping rhizome. Their leaves are plicate and non-articulate. The resupinate flowers are produced in succession and arranged in the terminal raceme. All tepals are free and similar in form. The clawed, 3-lobed lip is ornamented with 1-3 calli running along the central part of the disc. The elongate gynostemium is somewhat arcuate, slender in the lower half and slightly swollen at the apex. Currently Psilochilus includes about 15 species (Rothacker 2007; Kolanowska 2013; Kolanowska \& Szlachetko 2012, 2013) distributed from southern Mexico and the Caribbean to Brazil in the south. They usually grow as terrestrials, typically in wet montane 
and cloud forest, but there are several reports of epiphytic or lithophytic populations from Central America (Rothacker 2007). The altitudinal range of the genus extends from 200 to $2500 \mathrm{~m}$ a.s.l. Ortiz Valdivieso and Uribe Vélez (2007) provided information on only three Psilochilus species from Colombia: P. carinatus Garay, P. macrophyllus (Lindl.) Ames and P. maderoi Schltr. In the last three years, two additional species were described based on Colombian material: P. antioquiensis Kolan. and P. vallecaucanus Kolan. \& Szlach. (Kolanowska et al. 2014).

The genus Elleanthus was described by the Czech botanist Karel (Carl) Bořivoj Presl (1827). Its representatives are usually middle-sized to large plants occasionally reaching up to $5 \mathrm{~m}$ tall, with a sympodial cane-like stem, numerous plicate, often stiff leaves, and a terminal, elongate, usually many-flowered inflorescence. The flowers are middle-sized or small, non-respuinate and brightly colored. The sepals and tepals can be subsimilar or dissimilar, often furfuraceous on the outer side. The lip is saccate at the base, with two corpuscules at the bottom; its apical margin is fringed, dentate or erose. The gynostemium is erect, with an erect to subincumbent anther. The geographical range of Elleanthus extends from Mexico through Central America along with the Greater and Lesser Antilles and on to the tropical and subtropical regions of South America. These terrestrial plants grow in montane and submontane cloud forest, evergreen rain forest, humid savannah and grassy slopes. They are often found along roadsides. Infrequently, Elleanthus species are reported growing on tree trunks or larger branches. Sixty of the almost 150 Elleanthus species have been reported from Colombia (Ortiz Valdivieso \& Uribe Vélez 2007).

\section{MATERIAL AND METHODS}

Dried herbarium specimens and flowers preserved in liquid, deposited or borrowed from COL, HUA, K, MEDEL, MO, NY, PSO, RPSC, UGDA, VALLE and $\mathrm{W}$, were examined according to standard procedures. Herbarium acronyms are cited following Thiers (2015). Each specimen was photographed and the data from the label were taken. Leaf form and floral bract shape were studied first. Perianth parts and ovary structure were examined under a stereomicroscope after softening the flowers in hot water immediately after it was taken off the boil.

\section{NEW RECORDS}

Psilochilus modestus Barb. Rodr. Fig. 1

Gen. Sp. Orchid. 2: 273. 1882 - NeOTYPE (Rothacker 2007): Barbosa Rodrigues's illustration in Iconographie des Orchidées du Brésil, vol. III, part IV, reproduced by Sprunger). - Pogonia modesta (Barb. Rodr.) Cogn. in Mart., Flora Brasiliensis, Orchid. 3(4): 133. 1893.

Leaves in upper part of stem damaged, distinctly petiolate; petiole up to $1.5 \mathrm{~cm}$ long; blade $8 \mathrm{~cm}$ long, $3.8 \mathrm{~cm}$ wide, ovate to elliptic, obtuse. Inflorescence $9 \mathrm{~cm}$, subdensely 10-15-flowered. Floral bracts up to $12 \mathrm{~mm}$ long. Pedicellate ovary up to $16 \mathrm{~mm}$ long. Sepals with small glandulae on outer surface. Dorsal sepal $18 \mathrm{~mm}$ long, $3 \mathrm{~mm}$ wide, oblong-narrowly oblanceolate, acute, 5-veined, keeled. Petals $17 \mathrm{~mm}$ long, $2.6 \mathrm{~mm}$ wide, falcate, narrowly ligulate-lanceolate, obtuse, 3-veined. Lateral sepals $18 \mathrm{~mm}$ long, $3 \mathrm{~mm}$ wide, falcate, oblanceolate, acute, 5-nerved, keeled. Lip $17 \mathrm{~mm}$ long in total, clawed, 3-lobed; claw less than a third of total lip length; lateral lobes obliquely ovate, obtuse, extending to base of middle lobe, slightly crenate along margins; middle lobe $4 \mathrm{~mm}$ long, $5 \mathrm{~mm}$ wide, suborbicular, margins crenate; disc

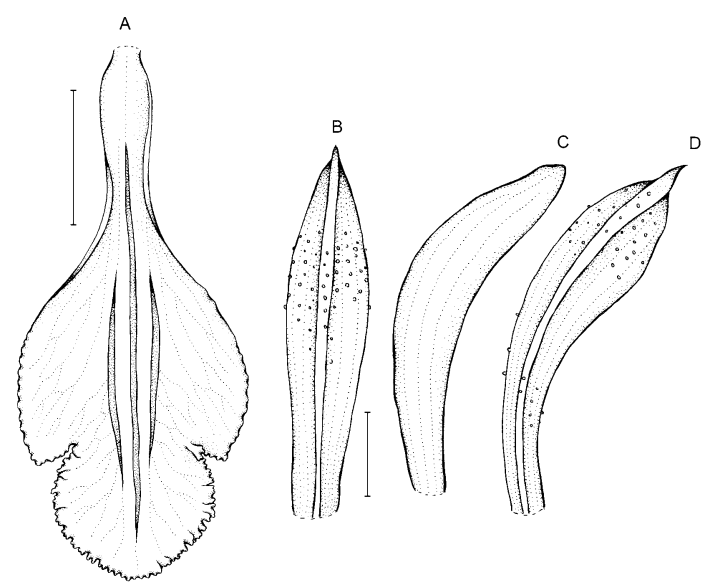

Fig. 1. Psilochilus modestus Barb. Rodr. A - lip, B - dorsal sepal, C - petal, D - lateral sepal. Scale bar $=4 \mathrm{~mm}$. Drawn by A. Król from Holton s.n. (NY). 
with three keels or thickened veins. Gynostemium ca $15 \mathrm{~mm}$ long.

ECOLOGY. Terrestrial, in organic soil in the shade of trees in montane wet forest. Flowering in July.

General distribution. Bolivia, Brazil, Colombia, Jamaica, Venezuela.

Representative Specimens: COlOMBIA. Cundinamarca. Fusagasuga. Holton s.n. (NY!).

Probably the following collection represents the same species. Unfortunately it bears no flowers, making reliable identification impossible: COLOMBIA. Magdalena. Sierra Nevada de Santa Marta. Transecto del Alto Rio Buritaca. Cuchilla. Alt. 1700 m. 16 July 1977. R. Jaramillo M., van de Hammen, Cleef \& O. Rangel $5163 \& 5187 a$ (COL! - sterile).

Other MATERIAL EXAMINED: JAMAICA. Sine loc. Morris 2090 (W!).

Notes. This species was previously known from Bolivia, Brazil and Venezuela, and unconfirmed records come from Ecuador and Colombia (Kolanowska et al. 2014). Rothacker (2007) considered $P$. modestus to be synonymous with P. maderoi, but in P. modestus the claw is short, while in $P$. maderoi the claw may represent even half of total lip length. Moreover, the lateral lobes of the latter species are obtuse to rounded, whereas in P. modestus they are acute.

\section{Elleanthus hirtzii Dodson}

Fig. 2

Orquideologia 19(2): 136. 1994; HоLOTYPE: C. Dodson, T. Neudecker \& H. Volles 18646 (RPSC!) - IsOTYPE: QCNE.

Stem up to $35 \mathrm{~cm}$ tall, cane-like, arcuate, elongate, slender, delicate, unbranched, the basal half leafless, few-sheathed, the apical half with several leaves. Leaves up to $15 \mathrm{~cm}$ long and $2.4 \mathrm{~cm}$ wide, oblong-lanceolate, narrowly to broadly lanceolate, acuminate, plicate, distichous, sessile, thin. Inflorescence $2-4 \mathrm{~cm}$ long, terminal on leafless stem or with one or two reduced leaves toward apex, subdensely many-flowered, cylindrical. Flowers green, lip with whitish margin. Floral bracts to $10 \mathrm{~mm}$ long, cymbiform, acute, shorter than ovaries. Ovary and pedicel to $20 \mathrm{~mm}$ long, cylindrical, glabrous. Dorsal sepal up to $7 \mathrm{~mm}$ long and $3 \mathrm{~mm}$ wide, oblong-obovate to ligulate-
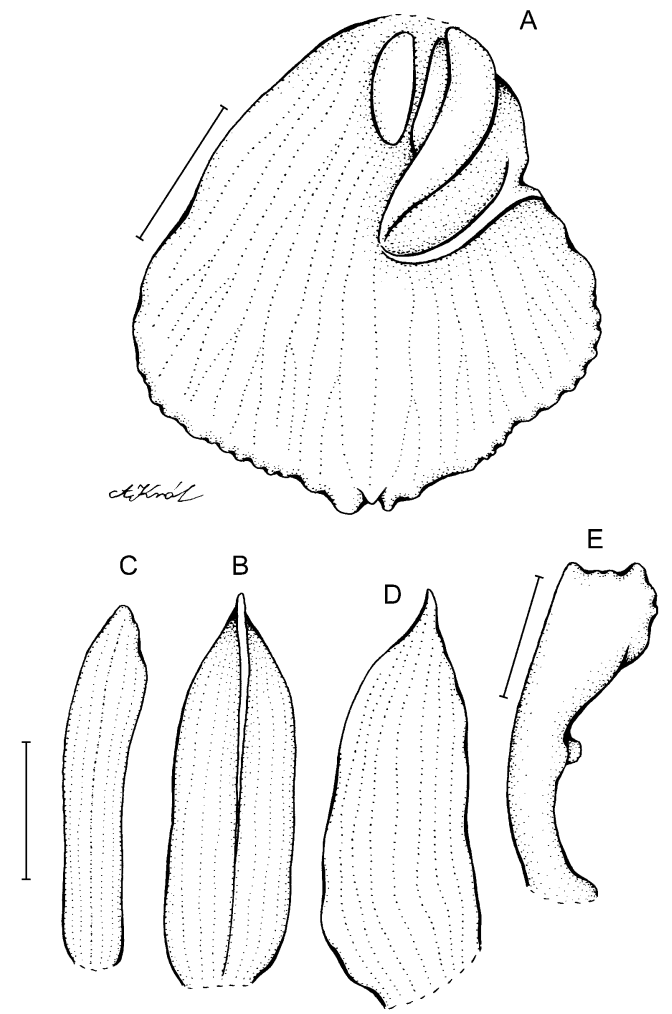

Fig. 2. Elleanthus hirtzii Dodson. A - lip, B - dorsal sepal, $\mathrm{C}$ - petal, D - lateral sepal, E - gynostemium. Scale bar = $3 \mathrm{~mm}$. Drawn by A. Król from Dodson et al. 16876 (RPSC).

oblanceolate, acute, 5-nerved. Petals up to $7 \mathrm{~mm}$ long and $3 \mathrm{~mm}$ wide, narrowly lanceolate to linearlanceolate, acuminate, subfalcate, margin entire, 5-nerved. Lateral sepals up to $8 \mathrm{~mm}$ long and $4 \mathrm{~mm}$ wide, obliquely oblong-ovate, elliptic-ovate to ligulate-oblanceolate, acuminate, not carinate toward apex, concave at base, 7-nerved. Lip up to $8 \mathrm{~mm}$ long and $12 \mathrm{~mm}$ wide, flabellate to broadly ovateelliptic, in front subtrilobate, truncate across apex, irregularly denticulate, subglobose-ventricose at base containing a pair of globose, proximate corpuscules located at the very base of the cavity, apex of cavity slightly thickened to form transverse ridge. Gynostemium $5 \mathrm{~mm}$ long, slender, not hooding the anther.

ECOLOGy. Epiphytic. In Colombia this species was found growing at road margins. Flowering in November. 
General Distribution. Ecuador, Colombia.

Representative SPeCimens: COLOMBIA, Risaralda. Municipio Pueblo Rico, vereda Monte Bello, Cerro Montezuma. $5^{\circ} 14^{\prime} 53.5^{\prime \prime} \mathrm{N}, 76^{\circ} 06^{\prime} 13.7^{\prime \prime} \mathrm{W}$. Alt. 2249 m. 15 Nov. 2006. R. Arevalo \& A. Tapasco 719 (COL!).

OTHER MATERIAL EXAMINED: ECUADOR. Imbabura. $8 \mathrm{~km} \mathrm{E}$ of Lita on road to Ibarra and $8 \mathrm{~km}$ up road from Cachaco to Santa Rosa de Cachaco to elevation of $1150 \mathrm{~m}$, and hiked up ridgeline to $1550 \mathrm{~m}$ alt. 19 Jan. 1987. C. Dodson, A. Hirtz, D. Benzing, C. Luer \& J. Luer 16876 (RPSC! - paratype); Lita-Ibarra, $8 \mathrm{~km}$ $\mathrm{S}$ of road entering from $8 \mathrm{~km}$ on road Cachaco to Santa Rosa de Cachaco, then up old trail to Rio Verde. Alt. 1200-1500 m. 30 Dec. 1990. C. Dodson, T. Neudecker \& H. Volles 18646 (RPSC!).

Notes. This species is easily separable from all other Elleanthus species by its erect flowers with long ovaries, much exceeding the bracts and flower parts.

ACKNOwLEDGEMENTS. We thank the Curators and staff of the cited herbaria for their kind hospitality and assistance during visits, Anna Król for preparing the illustrations, and the anonymous reviewers for helpful remarks on the manuscript. The research described here was supported by the Polish Ministry of Science and Higher Education (research grant no. 8124/B/ PO1/2011/40).

\section{REFERENCES}

Barbosa Rodrigues J. 1882. Genera et species Orchidearum novarum. 2. Typographia Nacional, Sebastianópolis.

Jørgensen P. M., Ulloa Ulloa C., León B., León-YÁnez S., Beck S. G., Nee M., Zarucchi J. L., Celis M., Bernal R. \& GRADSTEIN R. 2011. Regional patterns of vascular plant diversity and endemism. In: S. K. Herzog, R. Martínez, P. M. Jørgensen \& H. Tiessen (eds), Climate change and biodiversity in the tropical Andes, pp. 192-203. InterAmerican Institute for Global Change Research (IAI) and Scientific Committee on Problems of the Environment (SCOPE).

KolanowsKa M. 2012. The first record of Platystele ximenae (Pleurothallidinae, Orchidaceae) for Colombia. Biodiv. Res. Conservation 25: 39-42.
KolanowsKa M. 2013. Psilochilus antioquiensis (Triphoreae, Orchidaceae), a new species from Colombia. Ann. Bot. Fenn. 50: 115-118.

Kolanowska M. \& SzlachetKo D. L. 2012. A new species of Psilochilus (Triphoreae, Orchidaceae) from Colombia. Syst. Bot. 37: 352-355.

Kolanowska M. \& Szlachetko D. L. 2013. Psilochilus tuerckheimii (Orchidaceae), a new species from Guatemala. Ann. Bot. Fenn. 50: 309-311.

Kolanowska M., Medina T. R., Szlachetko D. L. 2013. Un nuevo registro de Porroglossum (Pleurothallidinae) en la flora de orquídea colombiana. Orquideología 30(2): 76-83.

Kolanowska M., SzlachetKo D. L. \& Kras M. 2014. Synopsis of the genus Psilochilus (Orchidaceae) in Colombia. Syst. Bot. 39(3): 750-758.

Kolanowska M., Szlachetko D. L., Medina Trejo R. \& BARRERA G. C. 2012. New record of Orchidaceae from Colombia. Orquideología 29(2): 102-111.

Meisel J. \& Woodward C. 2005. Andean orchid conservation and the role of private lands: A case study from Ecuador. Selbyana 26(1 \& 2): 49-57.

Orejuela J. E. 2005. An integrated approach to orchid conservation in Colombia: What do orchids, hummingbirds, bears, potable water, and indigenous land rights have in common? Selbyana 26: 32-45.

Ortiz Valdivieso P. \& URiBe Vélez C. 2007. Galería de Orquideas de Colombia (CD edition). Asociación Bogotana de Orquideología, Bogotá.

Pérez Escobar O. A., Parra Sánchez E., Kolanowska M. \& Ortiz VAldivieso P. 2011. Primer reporte de Telipogon lankesteri Ames (Orchidaceae) para Colombia. Orquideologia 28(1): 36-40.

Pérez Escobar O. A., Ortiz Valdivieso P., Parra SánCHez E., Rincón Useche C. \& Rodríguez L. K. 2013. Novelties in Orchidaceae for the Colombian flora. Lankesteriana 13(1-2): 135-136.

Presl C. B. 1827. Orchideae Juss. In: T. Haenke (ed.), Haenkeanae seu descriptiones et icones plantarum quas in America Meridionali et Boreali, in Insulis Phillipinis et Marianis Collegit, pp. 91-104. Calve, Prag.

Rothacker E. P. 2007. The primitive Epidendroideae (Orchidaceae): phylogeny, character evolution and the systematics of Psilochilus (Triphoreae). Ph.D. dissertation. Ohio State University, Columbus.

Thiers B. 2015. Index Herbariorum: A global directory of public herbaria and associated staff. New York Botanical Garden's Virtual Herbarium. http://sweetgum.nybg.org/ih. 